\title{
Determinants of Technical In-efficiencies in Swamp Rice Farming - Ciamis District, Indonesia
}

\author{
Agus Yuniawan Isyanto*, Sudrajat Sudrajat, and Muhamad Nurdin Yusuf \\ Agribusiness Department, Faculty of Agriculture, Universitas Galuh, \\ Jl. R.E. Martadinata No.150, Ciamis 46274, Indonesia
}

\begin{abstract}
Rice farming in swamps, a marginal land, has a relatively high risk related to the level of technical efficiency. This research was conducted with the aim of identifying the level of technical efficiency and the influence factors of technical inefficiency in Lakbok Subdistrict, Ciamis District, Indonesia. Simple random sampling was used with a sample size of 41 farmers. The analysis was carried out using a stochastic frontier function. The results showed that the average level of technical efficiency was 0.78 . Education and family size have a significant effect on technical inefficiency.
\end{abstract}

Keywords: Farmer, marginal land, stochastic frontier

\section{Introduction}

Swamp rice grows in marginal land that has a relatively high risk related to the level of technical efficiency [1]. This farming is carried out in the dry season where water needs depend on rainfall [2]. Swamp rice farming usually faces serious challenges during the rainy season [3].

The main problem in the management of swamp rice farming is the occurrence of floods that inhibit plant growth and production. Farmers in swamp rice often have difficulty in predicting flood levels, so they face the risk of flooded rice plants in the vegetative growth phase [4]. Weather and climate have a direct influence on agricultural production so that weather fluctuations and climate variability play an important role in growth and yields [5].

The crucial problem of rice farming in Indonesia is the low efficiency and productivity thus the production is uncompetitive compared to other rices. Increased rice production can be done through existing technology [6]. Technical efficiency compares the level of output in relation to the level of input used [7].

Lack of skilled farmers in managing the system properly causes inefficient agricultural management leads to reduced yields and increased waste [8]. The low yield is due to several factors including agro-climatological problems and high input costs [9]. Constraints in increasing crop yields can be related to inefficient agricultural management even though inputs are used intensively [10].

The ability to allocate factors of production will affect production and the level of efficiency. The non optimal production indicates the existence of technical inefficiencies [11].

This research was conducted with the aim of identifying the level of technical efficiency and the factors that influence technical inefficiency in swamp rice farming in Lakbok Subdistrict, Ciamis District, Indonesia.

\footnotetext{
*Corresponding author: gusyun69@gmail.com
} 


\section{Methods}

The research was conducted in Lakbok Subdistrict, the only sub district that has swamp lanswampland farming. The research was carried out for 3 mo in planting the first season.

The sample size was 41 farmers using simple random sampling. The study utilized stochastic production frontier which builds hypothesized efficiency determinants into the inefficiency error components. The model is defined by Equation (1):

$$
\ln Y=\beta_{0}+\beta_{1} \ln X_{1}+\beta_{2} \ln X_{2}+\beta_{3} \ln X_{3}+\beta_{4} \ln X_{4}+\beta_{5} \ln X_{5}+v i-u i
$$

Where:

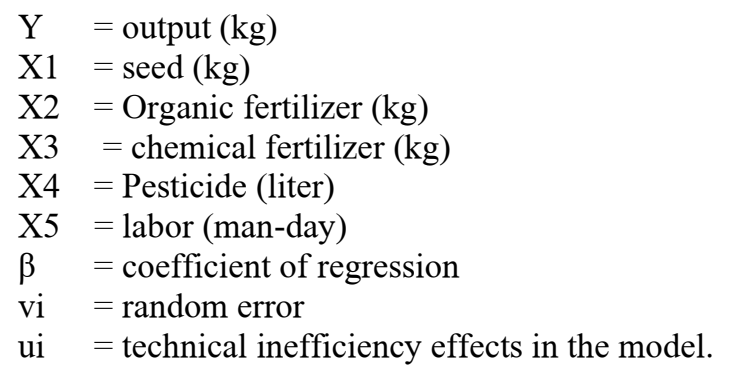

Technical efficiency (TE) effects model developed by Battese and Coelli was employed in this study. In this model a Cobb-Douglas production function and some exogenous factors influencing technical efficiency are determined simultaneously.

Technical efficiency in the context of production relates to the level at which a farmer produces maximum feasible output from a given set of inputs (output-oriented measure), or uses a minimum level of input feasible to produce a certain level of output (a size-oriented input) [12].

Inefficiency model was defined to estimate the influence of some farmer's socioeconomic variables on the technical efficiency of the farmers. Technical inefficiency effects are assumed to be distributed independently $[13,14]$. The model was defined by Equation (2):

$$
\mu \mathrm{i}=\delta_{0}+\delta_{1} Z_{1}+\delta_{2} Z_{2}+\delta_{3} Z_{3}+\delta_{4} Z_{4}
$$

Where:

$\mu \mathrm{i}=$ technical inefficiency

$\mathrm{Z1}=$ age (years)

$\mathrm{Z} 2$ = education (years)

$\mathrm{Z3}=$ experience (years)

$\mathrm{Z} 4$ = family size (persons)

$\delta=$ regression coefficient.

\section{Results and discussion}

\subsection{Technical efficiency}

The level of technical efficiency achieved by rice farmers in swamps ranged from 0.53 to 1.00 with an average of 0.778 as presented in Table 1. 
Table 1. Frequency distribution of technical efficiency

\begin{tabular}{|c|c|c|}
\hline $\begin{array}{c}\text { Technical } \\
\text { Efficiency }\end{array}$ & Frequency & Percentage \\
\hline 0.51 to 0.60 & 5 & 12.20 \\
\hline 0.61 to 0.70 & 6 & 14.63 \\
\hline 0.71 to 0.80 & 9 & 21.95 \\
\hline 0.81 to 0.90 & 11 & 26.83 \\
\hline 0.91 to 1.00 & 10 & 24.39 \\
\hline \multicolumn{3}{|c|}{ minimum $=0.53$; maximum $=1.00 ;$ mean $=0.78$} \\
\hline
\end{tabular}

Table 1 showed that the average level of technical efficiency achieved was 0.78 , which indicates that swamp rice farming was technically efficient. This efficiency index value implied a technical inefficiency gap of 0.22 which indicates that $22 \%$ of higher production can be achieved by farmers without using additional resources, or the use of inputs can be reduced to achieve the same level of output. The technical efficiency will be considered as efficient if it reaches an efficiency index value of more than 0.70 [15]. The difference in the level of technical efficiency achieved by farmers shows the degree of differentiation in the application of technology [16].

\subsection{The stochastic frontier production functions analysis}

Analysis of factors affecting production and technical inefficiencies was carried out using the stochastic frontier production function as presented in Table 2.

Table 2. Maximum likelihood estimates and inefficiency functions

\begin{tabular}{|l|c|c|c|}
\hline \multicolumn{1}{|c|}{ Variable } & Coefficient & $\begin{array}{l}\text { Standard } \\
\text { Error }\end{array}$ & t-ratio \\
\hline Production function & 3.1067 & 0.6518 & 4.7666 \\
Constant & -0.0668 & 0.2408 & -0.2774 \\
Seed & -0.0013 & 0.0133 & -0.1008 \\
Organic fertilizer & -0.0454 & 0.1651 & -0.2753 \\
Chemical fertilizer & -0.0994 & 0.0916 & -1.0858 \\
Pesticide & 1.3531 & 0.4388 & $3.0839^{*}$ \\
Labor & & & \\
Inefficiency function & -0.2092 & 0.0680 & 3.0756 \\
Constant & -4.8680 & 0.4471 & 0.1089 \\
Age & 0.3088 & 0.0114 & $27.0778^{*}$ \\
Education & -0.1194 & 0.3280 & -0.3641 \\
Experience & -0.0085 & 0.0014 & $-5.9857^{*}$ \\
Family size & -0.0565 & 0.0034 & 16.3768 \\
Sigma squared & 0.9999 & 0.0024 & 425.2544 \\
Gamma & 18.2348 & \\
\hline Log likelihood function & 12.8942 & & \\
LR Test & \multicolumn{3}{|l}{} \\
\hline
\end{tabular}

*significant at $1 \%(\mathrm{p}>0.01)$

The estimated value of the gamma parameter $(\gamma)$ of 0.9999 is statistically different from zero. This indicated that $99.99 \%$ of the variation in the level of output in swamp rice farming is caused by technical inefficiencies in the use of inputs. The model used in this 
study is a linear log equation hence the value of each regression coefficient shows the production elasticity of each input. The sum of all regression coefficients is more than one (1.13) which indicates increasing returns to scale.

Table 2 showed only the labor force that has a positive and significant effect on production in swamp rice farming. The results of this study were in line with the other research $[1,17]$.

\subsection{Technical inefficiency}

Table 2 showed that education has a positive and significant effect on technical inefficiencies, which shows that improving education will reduce technical efficiency. Family size has a negative and significant effect on technical inefficiency which indicates that increasing family size will increase technical efficiency. The results of this study are in line with the results of another research [18].

Age has a negative but not significant effect on the level of technical inefficiency which indicates that the older the farmer, the more technically efficient. The results of this study are consistent with other findings [19].

Education has a positive and significant effect on technical inefficiency which shows that the more educated farmers, the lower the technical efficiency. The results of this study are in line with other findings [20].

The experience of farmers in swamp rice farming has a negative but not significant effect on the level of technical inefficiency. This shows that the more experienced farmers in carrying out swamp rice farming will increase their technical efficiency. The results of this study are consistent with other findings [21].

Family size has a negative but not significant effect on the level of technical inefficiency. This shows that the more family size will increase the technical efficiency. More family size means more workers are available to carry out rice farming activities in swamps in a timely manner thus the production process becomes more efficient [6]. Farmers who have large family sizes tend to try their best to get higher yields to meet the needs of their families. In addition, large family sizes have the workforce needed to implement agricultural management decisions [22].

\section{Conclusion}

The level of technical efficiency of swamp rice farming ranged from 0.53 to 1.00 with an average of 0.778 which indicated that swamp rice farming has reached a level of technical efficiency. Labor has a significant effect on production, while seeds, organic fertilizers, chemical fertilizers and pesticides have no significant effect. Education and family size have a significant effect on technical inefficiency, while age and experience have no significant effect.

\section{References}

1. M. Zakirin, E. Yurisinthae, N. Kusrini, J. Soc. Econ. Agric. 2,1:75-84(2013). http://dx.doi.org/10.26418/j.sea.v2i1.5122

2. I. Zahri, S. Adriani, E. Wildayana, Sabaruddin, M.U. Harun, Bulg. J. Agric. Sci. 24,2:189-198(2018). https://www.agrojournal.org/24/02-03.pdf

3. K.J. Ani, G. Maxwell, C.S. Ecoma, Int. J. Adv. Academic Res. 3,4:1-10(2017). https://www.ijaar.org/articles/Volume3-Number4/Arts-Humanities-Education/ijaarahe-v3n3-m17-p4.pdf 
4. Gribaldi, R.A. Suwignyo, M. Hasmeda, R. Hayati, Agrivita 38,1:64-72(2016). http://doi.org/10.17503/agrivita.v38i1.498

5. A.V. Nkiene, N. Clement A, T. Paul, Canadian J. Trop. Geography. 3,2:1-14(2016). https://www3.laurentian.ca/rcgt-cjtg/volume-3-issue-2/3011/?lang=en.

6. J. Mariyono, Jurnal Ilmu Administrasi dan Organisasi 21,1:35-43(2014). [in Bahasa Indonesia]. http://journal.ui.ac.id/index.php/jbb/article/view/4042

7. M.M. Islam, D.C. Kalita, Int. J. Agric. Sci. 6,2:938-948(2016). https://doi.org/10.46882/IJAS/1231].

8. Nurliza, E. Dolorosa, A.H.A. Yusra. Agribis. 3,2:85-92(2017). https://doi.org/10.18196/agr.3248

9. O.M. Bamiro, J.O. Aloro. Scholarly J. Agri. Sci. 3,1:31-37(2013). http://www.scholarlyjournals.com/sjas/archive/2013/jan/pdf/Bamiro\%20and\%20Aloro.pdf

10. B. Ayedun, A. Adeniyi, Acta Sci. Nutr. Health. 3,7:86-94(2019). https://actascientific.com/ASNH/pdf/ASNH-03-0325.pdf

11. T.S Azwar, T.I. Noor, Ernah, Mimbar Agribisnis, 5,2:276-292(2019). [in Bahasa Inodensia]. https://jurnal.unigal.ac.id/index.php/mimbaragribisnis/article/view/2264

12. J.N Ugwu, G.O. Mbah, N. Chidiebere-Mark, T. Ashama, D.O. Ohajianya, M.O. Okwara, Current Res. Agric. Sci. 4,1:1-6(2017). https://doi.org/10.18488/journal.68/2017.4.1/68.1.1.6

13. M. Bala, M.N. Shamsudin, A. Radam, I.A. Latif. CSSPO International Conference 2018, Sarawak, Malaysia 2018. E3S Web of Conferences. 52:00030(2018).

https://www.e3sconferences.org/articles/e3sconf/pdf/2018/27/e3sconf_nrm2018_00030.pdf

14. M.F. Alam, M.A. Khan, A.S.M.A. Huq. Aquacult Int. 20:619-634(2012). https://link.springer.com/article/10.1007/s10499-011-9491-3

15. H. Khotimah, R. Nurmalina, Forum Agribisnis 2,2:141-160(2012). [in Bahasa Indonesia]. http://journal.ipb.ac.id/index.php/fagb/article/view/8882

16. A.Y. Isyanto, M.I. Semaoen, N. Hanani, Syafrial, J. Econ. Sustain. Dev. 4,10:100104(2013). https://iiste.org/Journals/index.php/JEDS/article/view/6518

17. D.L. Pudaka, Rusdarti and P.E. Prasetyo. J.Econ. Education. 7,1:31-38(2018). https://journal.unnes.ac.id/sju/index.php/jeec/article/view/22799

18. M. Mukwalikuli. WJRR. 6,4:60-65(2018). https://www.wjrr.org/download_data/WJRR0604025.pdf

19. Y. U. Oladimeji and Z. Abdulsalam, IOSR-JAVS. 3,3:34-39(2013). https://doi.org/10.9790/2380-0333439

20. B.S. Balde, H. Kobayashi, M. Nohmi, A. Ishida, M. Esham, E. Tolno. J. Agric. Sci. 6,8:179-196(2014). https://doi.org/10.5539/jas.v6n8p179

21. M.E.A. Begum, M.A.M. Miah, M.A. Rashid, M.I. Hossain. Factors affecting the technical efficiency of turmeric farmers in the slash and burn areas of Bangladesh. [Online] from https://doi.org/10.1007/s10457-018-0338-z. (2011) . [Accessed on 20 September 2019].

22. U. Mukhtar, Z. Mohamed, M.N. Shamsuddin, J. Sharifuddin, M. Bala. E3S Web of Conferences 52:00049 (2018). https://doi.org/10.1051/e3sconf/20185200049 